\title{
Die Vaktaal vir Elektronika en Drywingselektronika in Afrikaans
}

\author{
J.D. van Wyk \\ Departement Elektriese en Elektroniese Ingenieurswese, R.A.U., Posbus 524, Johannesburg 2000
}

\section{INLEIDING}

\section{Die vorming van vaktaal vir Elektronika}

Die Elektronika is een van die vakgebiede binne die Ingenieurswese wat geweldig vinnig uitbrei. Hieruit ontstaan 'n deurlopende uitdaging om te besin oor nuwe woorde wat in die vaktaal opgeneem kan word - veral aangesien daar tans 'n sterk neiging bestaan om Engelse vakbrabbel (,jargon') direk te vertaal. In baie gevalle is die eindproduk van hierdie vertaling 'n lang, omslagtige en skewe woord, wat inderdaad ook nie verdien om inslag te vind nie. 'n Voorbeeld wat ek graag aanhaal is die Engelse vakbrabbel.

„ROM", wat moet beduie ,Read Only Memory". Ek het al pogings tot 'n Afrikaanse vertaling teengekom wat lui: 'n ,lees-alleen-geheue"! Dit vind gelukkig geen inslag nie, maar ongelukkig word die Engelse vakbrabbel dan net so gebruik - veral deur die generasies van studente aan ons Afrikaanse Universiteite se Fakulteite vir Ingenieurswese. Almal praat en skryf maar eenvoudig van 'n ,ROM'.

Die grondliggende probleem is egter dat hierdie vakbrabbel die betrokke elektroniese komponent nie korrek beskryf nie. Op die keper beskou is hierdie tipe van rekenaargeheue sekerlik nie een wat net ,gelees" kan word nie. Dit is 'n tipe geheue waarin 'n vaste waarde ,gestoor" word, en hierna kan dit herhaaldelik "gelees" word sonder om die vaste waarde in die geheue te beïnvloed. Die Engelse vakbrabbel is dus selfs tegnies foutief. In Duits vind 'n mens die tegnies korrekte woord vir hierdie tipe elektroniese komponent, naamlik „Festwertspeicher”. 'n Goeie Afrikaanse eweknie sou dus wees 'n ,,vasgeheue", na aanleiding van die uitdrukking wat reeds in Afrikaans bestaan vir onroerende goedere, naamlik ,vasgoed".

Die bostaande uiteensetting gee slegs 'n aanduiding van die probleme wat kan opduik by of die oorname van die Engelse vakbrabbel of 'n poging om dit direk te vertaal. 'n Gebied binne die Elektronika wat dikwels ook hieronder ly is die Drywingselektronika.

\section{Die naam ,Drywingselektronika"}

Die Engelse „Power Electronics” word dikwels in Afrikaans vertaal met ,kragelektronika". Myns insiens moet 'n mens egter ook na die Duitse en Nederlandse woorde vra:

Duits: Leistungselektronik

Nederlands: Vermogenselektronica (of -electronica)
Die begrippe „Leistung” of ,Vermogen" het reeds 'n goeie Afrikaanse ekwivalent in die Elektrotegniek, naamlik ,drywing”. Die vertaling ,krag-" kom in hierdie verband glad nie voor nie, en daarom lyk die aanvaarbare woord ,drywingselektronika”.

Hierdie woord is ook tegnies korrek. Dié vertakking van die elektronika (Power electronics/Leistungselektronik/Vermogenselektronica) het te doen met elektroniese stelsels en elemente waar die klem val op die hantering van 'n hoë arbeidstempo (gedefinieer in tegniese sin). Drywing is in hierdie konteks in Afrikaans 'n sinoniem vir arbeidstempo. Die tegniese begrip ,krag" het 'n sterk inslag in die rigting van die meganika, en kan nie werklik hier verdedig word nie.

\section{3. 'n Sistematiese opbou van vaktaal vir die drywings- elektronika}

Ten einde die opbou van die vaktaal vir die drywingselektronika sistematies aan te pak, moet vervolgens bepaal word waarmee die drywingselektronika gemoeid is, watter prosesse hierby op die spel ${ }^{2}$ is en watter elemente (Engels ,devices") benut word om die stelsels waarin hierdie prosesse afspeel, te struktureer.

3.1 Die drywingselektroniese stelsels bestaan uit samestellings van skakelelemente (,switching devices"). Die karakteristieke manier waarop die elemente in elke stelsel verbind is, word die topologie van die drywingselektroniese stelsel genoem. In hierdie topologie word die elektriese stroom in een tak nul (die stroom doof uit) en word dit omgeskakel na 'n ander tak ('n mutasie vind plaas) van die topologie. Die topologieë van drywingselektroniese stelsels het gevolglik die naam mutators. (Kom ook in Duits en Nederlands voor. Ontbreek egter as so 'n duidelike definisie in Engels.) Die verskillende tipes mutators moet aan die hand van hulle onderskeie funksies 'n naam kry.

3.2 In die mutators vind daar gevolglik die prosesse van stroomdowing en stroomkommutasie plaas. Die benadering van die verskillende subgroepe van hierdie prosesse moet gekies word na aanleiding van die oorsprong van die proses.

3.3 In die mutators word verskillende tipes skakelelemente (,switching devices") gebruik. Hierdie skakelelemente kan in die hoofgroepe van diodes, tiristors en transistors verdeel word. Die verskil- 
lende tipes van hierdie hoofgroepe moet in Afrikaans 'n naam kry, terwyl daar ook behoefte is aan 'n korrekte Afrikaanse benaming vir al die verskillende vorms en tipes strome en spannings wat hierdie elemente dra.

4. Die voorgestelde werkwyse

In enkele opeenvolgende aflewerings sal aandag ge- skenk word aan

- Stelselterminologie (Deel I)

- Terminologie wat verband hou met diodes (Deel II)

- Terminologie wat verband hou met tiristors (Deel III)

- Terminologie wat verband hou met transistors (Deel IV).

\title{
(Deel 1)
}

\section{Stelselterminologie vir Mutators in die Drywingselektronika}

\author{
J.D. van Wyk en C.G. Steyn
}

Departement Elektriese en Elektroniese Ingenieurswese, R.A.U., Posbus 524, Johannesburg 2000

\section{Mutator}

'n Mutator is 'n topologie van drywingselektroniese skakelelemente. Dit kan beskryf word as 'n koppeling tussen elektriese energiebronne of belastings van verskillende frekwensies. Die benaming van die mutator word steeds afgelei van sy funksie in die drywingselektroniese stelsel.

\section{Steller}

'n Drywingselektroniese steller is een of ander vorm van mutator wat gebruik word om as uitsetelement van 'n beheerstelsel die vloei van drywing elektronies te beheer.

\section{Verskillende vorms van 'n mutator}

3.1 Indien 'n mutator 'n koppeling vorm tussen bronne of belastings van wisselspanning of -stroom en gelykspanning of -stroom, dan ontstaan die volgende benamings:

(a) Indien die wisselspanningskant drywing aan die gelykspanningskant lewer, word die mutator 'n gelykrigter genoem.

(b) Indien die gelykspanningskant drywing aan die wisselspanningskant lewer, word die mutator 'n wisselrigter genoem.

3.2 Indien 'n mutator gebruik word as 'n gelykspanning na gelykspanning- of gelykstroom na gelykstroomomsetter deur 'n topologie te benut waar die ingang periodiek met die uitgang verbind word, ontstaan die familie van kappers.

(a) By 'n hoog-laag kapper verstel die mutator die ingangsgrootheid na 'n kleiner gemiddelde waarde aan die uitgang.

(b) By 'n laag-hoog kapper verstel die mutator die ingangsgrootheid na 'n hoër gemiddelde waarde aan die uitgang.

(c) By 'n laag-en-hoog kapper het die topologie die eienskap om die uitgangsgrootheid óf groter óf kleiner as die ingangsgrootheid af te lewer.

(d) By die familie van kappers is of die spanning óf die stroom aan die ingang 'n konstante grootheid en word dit aan die uitgang omgeskakel na 'n pulserende grootheid.

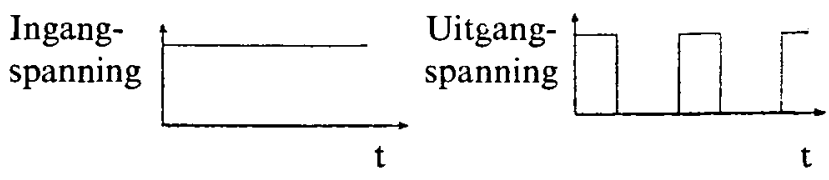

FIGUUR 1. Kapperspannings.

4. Die stroomgeleidingsprosesse in mutators

4.1 Ontsteking is die proses waarby die stroom in die skakelelement deur 'n eksterne proses aan die gang gesit word. Dit kan ook aanskakeling genoem word.

4.2 Dowing:

Die proses waar die stroom in 'n skakelelement na nul gereduseer word. Dit kan ook afskakeling genoem word.

4.3 Kommutasie:

Proses waar stroom van een skakelelement of stroombaan na 'n ander een weggelei word sodat die stroom in die oorspronklike element of stroombaan na nul reduseer.

4.4 Toevoerdowing:

Metode om 'n geleidende skakelaar te doof deurdat die toevoerbron die stroomrigting deur die skakelelement omkeer.

4.5 Lasdowing:

Metode waardeur 'n geleidende skakelelement gedoof word, deurdat die las die stroomrigting deur die skakelelement omkeer.

4.6 Natuurlike dowing:

Geskied wanneer die topologie van die mutator, in samewerking met die bron of die las, veroorsaak dat die stroom deur die betrokke skakelelement na nul reduseer.

4.7 Dwingdowing:

Dit is waar die dowing deur 'n eksterne bron of stroombaan teweeggebring word. 
4.8 Natuurlike ontsteekpunt (NOP)

Die vroegste tydstip waarop 'n nie-geleidende skakelelement stroom voorwaarts kan begin gelei. Van toepassing by wisselstroomwerking.

4.9 Natuurlike doofpunt (NDP):

Die punt waar die toevoerstroom van 'n positiewe na 'n negatiewe waarde verander en die skakelelement dan gedoof word.

4.10 Vertraaghoek $\alpha$ :

Die hoek, in elektriese grade, tussen die natuurlike ontsteekpunt en die punt waar die skakelelement werklik ontsteek word.

4.11 Doofhoek $\gamma$ :

Die hoek, in elektriese grade, tussen die natuurlike ontsteekpunt en die natuurlike doofpunt.

4.12 Stroomvloeihoek of geleihoek $\xi$ :

Die hoek, in elektriese grade, waartydens die skakelelement voorwaartse stroom dra. Die samehang tussen natuurlike ontsteekpunt, natuurlike doofpunt, vertraaghoek en doofhoek word deur die volgende figuur verduidelik:

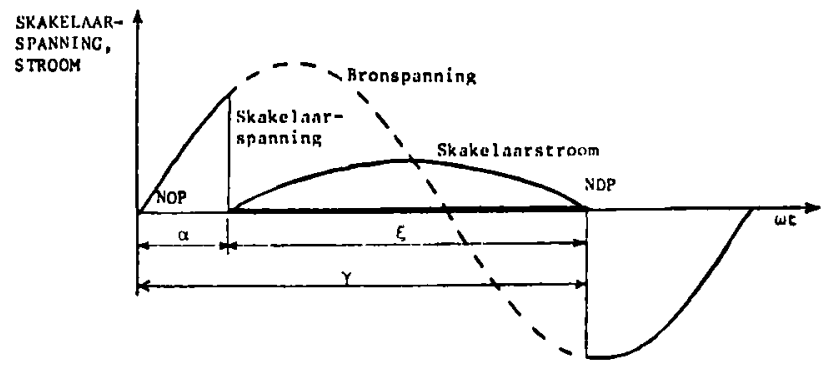

FIGUUR 2. Hoekclefinisies by wisselspanningwerking.

\section{Direkomsetters}

Direkomsetters is die familie van mutators waar twee elektriese bronne of belastings gekoppel word deur 'n topologie wat slegs skakelelemente bevat (m.a.w. elemente vir die stoor van energie in elektromeganiese of elektromagnetiese vorm is afwesig). In die algemeen word hierdie familie van mutators gebruik om 'n wisselspanning met vaste frekwensie om te skakel in 'n wisselspanning met veranderlike frekwensie. (Engels: Cycloconvertor. Duits: Direktumrichter). Figuur 3.
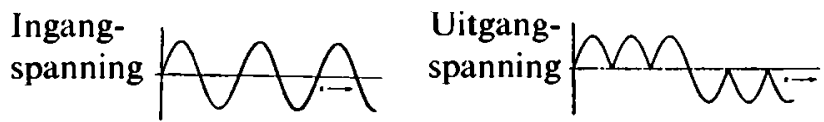

FIGUUR 3. Spannings by 'n direkomsetter.

6. Indien die bostaande in ag geneem word, kan die doof- en kommutasieprosesse in die mutator gedwonge of natuurlik wees, sodat die volgende familie ontstaan: (figuur 4).

MUTATORS (ws-gs)

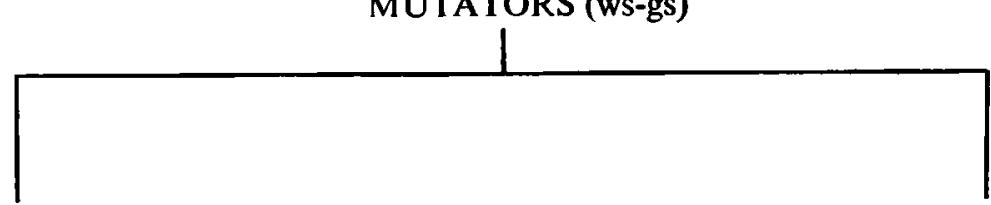

NATUURLIKE DOWING

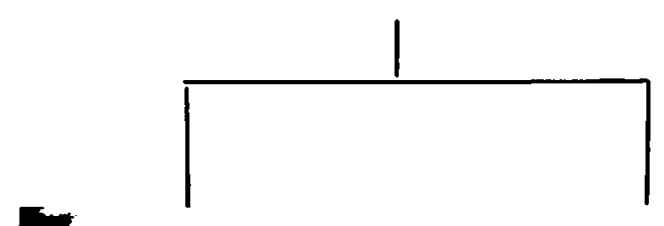

GELYKRIGTER
DWINGDOWING

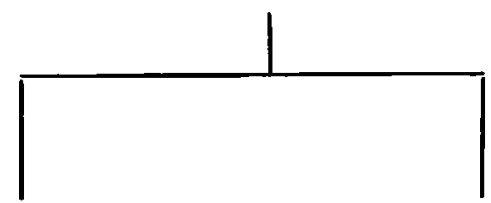

GELYKRIGTER

FIGUUR 4. Mutatorindeling. 